\title{
Research on the Developmental Trend of Education Pattern of the Contemporary College Students' Ideological and Political Education under the Background of Internet Era
}

\author{
Xueshi Yan \\ Agricultural University of Hebei, Baoding City, \\ Hebei Province, 071000 China
}

\begin{abstract}
In this paper, we conduct research on the developmental trend of education pattern of the contemporary college students' ideological and political education under the background of Internet era. The ideological and political education the popularization of scientific knowledge, promote the scientific spirit objectively functions, such as emancipating the mind and seeking truth from facts and keeping pace with the times is a kind of scientific spirit. Adhere to realize their own value and service in the motherland people's unity, is the value orientation of college students' all-round development and the ideal goal. Many difficulties and the problems that exist in the college students' all-round development, the urgent need to humanistic spirit education and the integration of scientific spirit education, expand the connotation of college students' all-round development in time according to the changing times. In the later research, we will discuss the corresponding issues in detail.
\end{abstract}

Keywords- Education Pattern, Ideological and Political, Internet Era, Developmental Trend.

\section{Introduction}

Ideological and political work in colleges and universities is the key of the any time in the university education work, in the new historical stage. Facing more complex social environment and the actual needs of college students' growth, strengthen and to improve ideological and political education work harder. Since the beginning of the ideological and political education value theory, it is educational world attention hot spot, has made great progress, but

\author{
Bo Ma \\ Agricultural University of Hebei, Baoding City, \\ Hebei Province,071000 China
}

the ideological and political education theory of individual value doesn't seem to keep up with the pace of development is relatively slow. The concept, so far there is no accurate definition. Under this circumstance, we demonstrate the corresponding core principles of the modern political work in colleges and universities as the follows.

- The characteristic of the age of the Internet is obvious and the network has strong dependence. With the coming of information age, the contemporary college students is good at using the Internet for all kinds of resources, but because of the network information content is good and evil people mixed up and they have been hit is good and bad are intermingled.

- On the code of conduct and attitude towards life. Diversified development trend. Has a strong patriotic enthusiasm, but owing to lack of the understanding of some social problems, that not comprehensive and objective view of the social problems are easily influenced by itself the restriction of objective conditions and the influence of the social climate.

- Personality is outstanding that have strong independent consciousness. Contemporary college students are mostly only children, living conditions is relatively superior and the pursuit of the individuality and self-consciousness strongly, like dealing with problems 
independently, good at through a variety of activities to show their ideas [1-2].

- Rebellion consciousness. Due to the strong individuality, contemporary college students will form their own view that dared to think some unreasonable phenomenon resistance.

Entering the new century, influenced by many factors and the status of the college students' group changed a lot. College students pay more attention to self-value and the realization of the interests as become desire and competition consciousness, growth, and more pragmatic, school conditions that to learn the living environment is more and more important. Pay to go to school and employment system reform that causes the student to the economic pressure, employment pressure. To improve the quality and effect of the ideological and political education, must be closely linked the ideological reality of the college students, pay attention to the different ways and means in the integrated use of ideological and political education, especially to pay great attention to the innovation of ideological and political education carrier, forms for those boring, one-way infusion, the lack of interaction of ideological and political education carrier to make the necessary processing, transformation and innovation. In figure one, we show the principles of the ideological and political education [3].

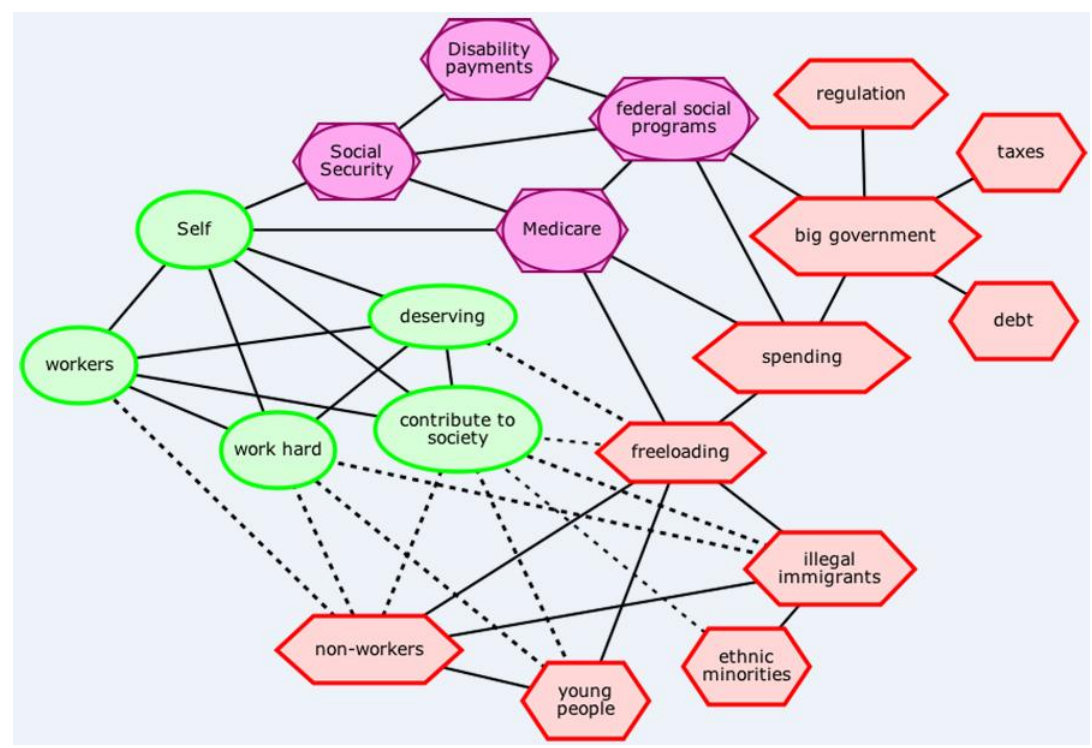

Figure 1. The Principles of the Ideological and Political Education

In this paper, we conduct research on the developmental trend of education pattern of contemporary college students' ideological and political education under the background of Internet era. Improve people's ideological and moral qualities and scientific and cultural quality, is the strategic requirement of the construction of the socialist culture power. Promote the scientific spirit, scientific and cultural development, cultivate scientific consciousness as helps to improve the level of scientific ideological and political education and enhance the national cultural soft power. In the following sub-sections, we will conduct more in-depth analysis to achieve better performance of the education.

\section{The Proposed Methodology}

The Modern University Education Reform. In the process of our country socialist economy rapid development, its own economic way also in change as a general background, the development of the applied undergraduate colleges should 
meet the demand of regional economic development and the industry economy development needs and the social development demand, etc., on the basis of the undergraduate course personnel training and education of undergraduate talent. But its defects and shortcomings still obviously, the economic development of their development way transformation is based on scientific and technological progress and management innovation, at the same time, labor quality and work quality is one of the two important factors, through analysis of the current situation of the development of economy and college, only applied undergraduate colleges and universities to timely update the teaching reform and education to promote the school and society common progress.

Classroom teaching is one of the most important link in the education of colleges and universities, is the most direct spread knowledge and opinion. Along with the advancement of teaching reform, classroom interaction has become the important means in today's teaching, but it did not stimulate students' enthusiasm to get participate in. How to realize the effective interaction, become an urgent problem of university teaching. To enhance the education function, we should follow the below list.

- By adjusting the discipline structure and improve general level of scientific research, provide scientific conditions for national development, at the same time, the innovation of science and technology into teaching resources application in education, realize education student. Further strengthen national policies and the combination of colleges and the universities and scientific research, to from a long-term perspective, and ultimately to ensure the implementation of the comprehensive reform [4-5].

- Construction of autonomous management system of colleges and universities, it is the system foundation for comprehensive reform in colleges. Specific rules and the regulations reform school, in the aspect of internal governance structure adjustment, strengthen the functions of the supervising agencies. In need of the national support, ready to policy space, win support from the state and consciously accept the supervision of the society and students to realize the reform and innovation.

- To cultivate innovative talents is the core of the university system innovation while promoting comprehensive reform of colleges and universities. In order to adapt to the development of the world diversity, our country universities should cultivate a group of diverse talents, have solid professional knowledge, and have the literature accomplishment and artistic thinking, with persistent belief finally occupy a place in the world talent trend.

Optimization of the structure of teaching staff, the need to focus on the introduction of teaching enthusiasm, a strong sense of responsibility of a master's degree in personnel and to enrich it to the teaching and management of post, training them to become the future backbone of teaching, scientific research, management, and distinguished a group of the senior professional and technical ability, rich experience in social practice, social practice talents as a part-time teachers, to strengthen the teaching and overall practice effectively [6].

The College Students' Ideological and Political Education. College students' ideological and the political education related to accept subject, object, accept medium body and environment, four complement each other, mutual influence, external dynamic structure is an open, every factor under a certain task. Only give full play to their respective role, the effect of the ideological and the political education to play the greatest energy. 


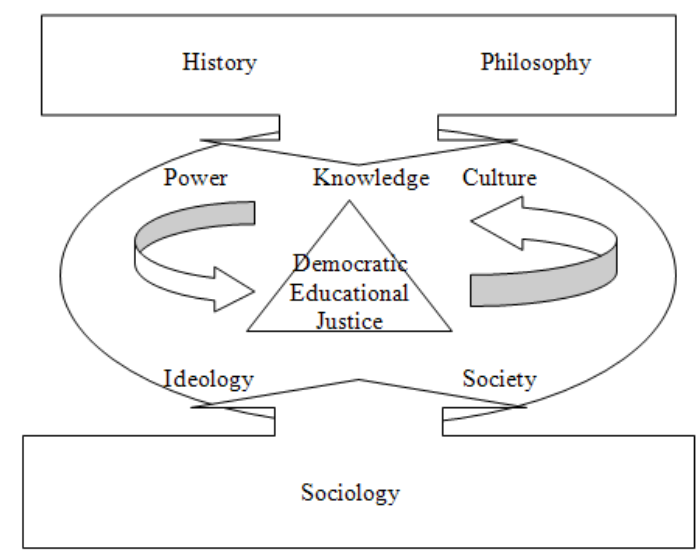

Figure 2. The Flowchart of the Ideological and Political Education

Improve the teaching quality of ideological and political education, which is based on the reality of ideological and basic political education effectiveness are poorer profound review and reflection. If contained in the ideological and political education of the ideological theory, values, ethics, political ideal, has not been the education object to their deep and stability of the ideological and political qualities, psychological structure and individual character consciousness, not as certain as to meet the requirements of social development of habits, then our ideological and political education did not play a proper role. Therefore, we should follow the listed aspects. (1) To build the whole college students ideological and political education supervision and evaluation mechanism. Improve the ideological and political education supervision evaluation mechanism is essential while it not only is the basic requirement of ideological and political education activities, and perfect the system of our country the current ideological and political education work of the specific requirements, its ultimate aim is to serve students that reflect the subjectivity of the college students. The feasibility of supervision and evaluation should include not only the ideological and basic political education work, the education resources utilization as well as the effect of ideological and the political education, but also should include educator education responsibility fulfillment situation, to ensure supervision and evaluation process of transparent and fair. Supervision mechanism needs to have certain innovative pioneering, in the process of work, to continually summarize historical experience and lessons, to strengthen the ideological and political education acceptance. (2) Change the way of the ideological and the political education. The way of ideological and political education has the characteristics of structure theory as multi-dimensional educators must be good at several ways for comprehensive education at the same time. College students' ideas and thoughts in growing complexity under the comprehensive influence of subjective and objective factors, pay attention to the comprehensive education way is beneficial to form the education resultant force. But the way of the comprehensive, in accordance with the general requirements of ideological and political education activities, development goals and characteristic rules and acceptable ability of college students, innovation and development of ideological political education to play the role of comprehensive education way [7].

The Education in the Internet Era. As a newly emerging things hatch pool of colleges and the universities, colleges and universities teachers and students more advanced, application of Internet higher education has caused a huge impact. One thousand years, continue the teaching mode of focus in class teaching mode and teaching tools to maintain a piece of chalk and blackboard, teaching content from the teacher gained a lot of books, the Internet to the changed all that, driving education level of ascension in an all-round way. Internet education content increase, and the education thought, the management idea, the education method, education method is more advanced, improve the quality of education, education to reduce costs, expand the study space, implement the colleges of education fairness between countries. The Internet will certainly change education, and 
extension education and then the traditional school education mode, unstoppable [8].

Institutions of higher learning management model based on intelligent decision-making system to carry out the effective work in schools, has the condition of colleges and universities should set up big data environment as soon as possible, in the cultivation of the talents, teachers construction, scientific research, education, management and campus life etc. widely collecting process data, using the visual analysis and data mining technology to fully contain rich in value. The novel education pattern under the background could be summarized as the follows. (1) The Internet is an interactive strong open space as it is for people to in-depth discussion on the Internet has provided a broad platform. At the same time, it also makes the Internet knowledge and the information is multifarious. (2) With the development of since the media technology based on Internet, surf the Internet is more and more reflects the mass and grassroots and freedom. This online learning knowledge to more people, laid the foundation very thick fair. The Internet became without walls, all-weather open, adapt to individual requirements of "class". (3) Just a few decades, since the birth of the Internet rapidly absorbed human make instant almost all of the new knowledge and new information. At the same time, along with the literature record technology, multimedia technology rapid development and progress, such as the Internet and the storage of the traditional culture of the human achievement. This makes the Internet become all human knowledge, the information of unprecedented big gathering. (4) Connect people all over the world, via the Internet from their end their mastery of the new information in time, their own thoughts and feelings, uploaded to the Internet, after precipitation, refining and processing, constantly supplement and gain the treasure house of human knowledge and information.

\section{Conclusion}

In this paper, we conduct research on the developmental trend of education pattern of contemporary college students' ideological and political education under the background of Internet era. Grasp the concept of the scientific development. The scientific outlook on development is the first point of the development, the core is people-oriented, the basic requirement is comprehensive, balanced and basic sustainable, overall consideration as its fundamental approach. The scientific outlook on development is the inevitable result of the Chinese society to carry forward scientific spirit, show the science the concern's for people's life that show the guidance of science to the social development. Our research proposes the novel perspectives of enhancing the general performance of the ideological and political education which holds specific meanings.

\section{Acknowledgement}

This paper is financially supported by the following projects. (1) Philosophy and social sciences of Baoding city planning research project: Research on the effective methodologies for college helped push the rooting process of socialist core values in Baoding (NO. 20140244). (2) The development of social science research project in the Hebei province: The Beijing-Tianjin-Hebei background of the development of agricultural cooperation of agriculture and forestry colleges and universities talents cultivation orientation (NO. 2015030457). (3) Ideological and political work of Baoding city research subject: Campus culture brand building practice of socialist core values with the concept of good stories in agricultural university (NO. BDSZYH006). 


\section{References}

[1] Meng, Wang. "The enlightenment role of the political socialization on improving college students' ideological and political education." Journal of Henan Institute of Science and Technology 9 (2011): 029.

[2] Lin, Yuliang. "Inter-subjective Ideological and Political Education in Recent Years-A Review." J. Pol. \& L. 8 (2015): 223.

[3] Liu, Shuang. "Research on College Students' Ideological and Political Education in the Mobile Environment." 2nd International Conference on Management Science and Industrial Engineering (MSIE 2013). Atlantis Press, 2013.

[4] Zhong, Chen, Chen Peng, and Song Xiaolan. "Research on the Modes of Ideological and Political Education for Private College Students of Minority Nationalities in the New Period: A Case Study on Whole-student Education in No. 3 Branch College for Nationalities of Nanchang Institute of Science \& Techn." The Science Education Article Collects 1 (2015): 009.
[5] Ma, Xueyu, et al. "How to play the role of network service in ideological and political education under the new situation." 2015 International Conference on Education Technology, Management and Humanities Science (ETMHS 2015). Atlantis Press, 2015.

[6] ZHANG, Ru, and Qian ZHANG. "Analysis of Effectiveness of Teaching Theory of Ideological and Political Education in Universities [J]." Theory Research 15 (2013): 180.

[7] Yang, Guan, et al. "The Enlightenment of the Eighteen Party Congress Spirit on TCM College Counselors in Enhancing Ideological Education of Freshmen." The Science Education Article Collects 2 (2013): 011.

[8] ZHU, Lin, and Jian-xun ZHANG. "Multidimensional Interactive Teaching of College Ideological and Political Theory." Journal of Ningbo University (Educational Science Edition) 4 (2012): 029. 